\title{
Evaluation of proteins in natural rubber latex gloves and pulmonary function amongst female nurses in two tertiary hospitals in southern, Thailand
}

\author{
Chompunuch Supapvanich, ${ }^{1,2}$ Andrew C Povey, ${ }^{2}$ Frank de Vocht ${ }^{3}$
}

\begin{abstract}
Background: Inhaled natural rubber latex (NRL) allergens in a healthcare environment can cause NRL sensitization and reduce pulmonary functions.
\end{abstract}

Objectives: To determine the amount of proteins and the effects of NRL gloves on the pulmonary functions of female nurses in two hospitals in the southern Thailand.

Methods: The study included 340 female nurses from two hospitals in which self-reported information and a blood sample were collected. NRL sensitization was determined by using a solid-phase enzyme-labeled fluoroenzymeimmunoassay for anti-NRLIgE antibodies. Proteins in NRL gloves were measured by a modified Lowry method. Pulmonary function was measured by a spirometer.

Results: The prevalences of respiratory effects self-attributed to NRL glove use and of NRL sensitization were 6.5 and $4.7 \%$, respectively. Four of the 16 sensitized nurses reported respiratory symptoms. NRL sensitized nurses had lower forced expiratory flow $\left(\mathrm{FEF}_{25-75 \%}\right.$ predicted value) than those who were non-sensitized (Adj. difference $=-12.56$, $95 \% \mathrm{CI}=-24.41$ to -0.70 ). Furthermore, examination gloves contained protein levels in the range of $111-250 \mathrm{mg} / \mathrm{dm}^{2}$. Difference types of NRL glove contained with different amount of proteins. NRL sensitization was more prevalent in nurses with high concentrations of proteins in NRL gloves $(p=0.04)$.

Conclusion: Sensitization to NRL was associated with a decrease in $\mathrm{FEF}_{25-75 \%}$ predicted value, indicating narrowing of the small airways of the lung. Use of gloves with low proteins can reducing NRL allergen exposure in these hospitals, which may reduce the risk of developing respiratory problems and NRL sensitization.

Key words: sensitization, pulmonary function, nurse, protein, glove

\section{Citation:}

Supapvanich, C., Povey, A. C., de Vocht, F. (2022). Evaluation of proteins in natural rubber latex gloves and pulmonary function amongst female nurses in two tertiary hospitals in southern,

Thailand. Asian Pac J Allergy Immunol, 40(3), 240-246. https://doi.org/10.12932/ap-310319-0530

\section{Affiliations:}

${ }^{1}$ Division of Public Health, Sirindhorn College of Public Health, Yala, Thailand

2 Centre for Occupational and Environmental Health, School of Health Sciences, Faculty of Biology, Medicine and Health, University of Manchester, Manchester Academic Health Centre, United Kingdom

Population Health Sciences, Bristol Medical School, University of Bristol, United Kingdom

\section{Corresponding author:}

Chompunuch Supapvanich

Division of Public Health in Community,

Sirindhorn College of Public Health Yala

91, Tesaban 1 Rd., Sateng sub-district, MuangYala district,

Yala 95000, Thailand

E-mail: chompunuch@yala.ac.th

\section{Introduction}

Using powdered latex gloves (PLGs) at work can result in Healthcare workers (HCWs) having a high risk of exposure to latex allergens. ${ }^{1}$ Cornstarch powder on PLGs has been reported as an natural rubber latex (NRL) allergen carrier. ${ }^{2}$ NRL allergens in powdered gloves can spread out as airborne particles in workplaces during the wearing and removing of PLGs. ${ }^{3}$ A high concentration of NRL allergenic proteins has been found in NRL gloves; particularly in PLGs. ${ }^{1,4}$ In hospitals 
where a high concentration of NRL aeroallergen was detected, HCWs were more likely to have symptoms, including runny nose, wheezing, shortness of breath, rhinitis, rhino-conjunctivitis and asthma ${ }^{5-8}$ with a prevalence ranging between $2.3-$ $4.8 \%$ of $\mathrm{HCWs}^{7,8}$

NRL allergy remains an occupational health concern, particularly in HCWs in developing countries such as Thailand due to the high cost of alternatives such as synthetic and powder-free gloves. ${ }^{9,10}$ In 2017, a study of NRL glove used in a university hospital in Thailand reported that PLG was mostly used in health care workers (95.6\%), while less than 3 percent of them used nirile gloves, powder free gloves and neoprene gloves. ${ }^{8}$ Furthermore, numerous medical instruments, such as surgical and examination gloves, catheters, blood pressure cuffs, tourniquets, stethoscopes, elastic bandages and wraps, containing NRL are also used in hospitals ${ }^{4,11}$ and high levels of NRL protein allergens have been reported in medical gloves, particularly PLGs. ${ }^{12,13} \mathrm{HCW}$ s who wear PLGs can be exposed to NRL protein allergens by cutaneous and/or respiratory routes. ${ }^{14-16}$ Such exposure can induce respiratory symptoms in NRL sensitized individuals. ${ }^{17}$

Changes in pulmonary function (e.g. a reduced $\mathrm{FEV}_{1}$ ) have been described. ${ }^{18}$ Respiratory reactions have been reported to occur even in those workers who no longer wear NRL gloves, but who stayed in the environment where PLGs were used. ${ }^{6}$ In a study amongst HCWs in the USA, NRL sensitized HCWs were more likely to leave employment within 2 years when compared with HCWs who were not sensitized to NRL. ${ }^{19}$ Hence there are significant health implications to the continuing use of PLGs in Thailand.

There is little information about the prevalence of health effects and on risk factors specifically related to NRL allergy in Thai HCWs, and so the aims of this study were to evaluate the amount of crude water soluble proteins in NRL gloves used in hospitals and to determine the effects of occupational use of NRL gloves on the pulmonary function and NRL sensitization of nurses in two tertiary hospitals in Thailand.

\section{Methods \\ Study design and population}

An analytical observational study was conducted among 664 female nurses working in two tertiary hospitals in the south of Thailand. All nurses wore NRL gloves at work. The study was approved by the hospital human right committees from two hospitals (Ref. YL0027.102/17050 and Ref. SK00 27.103/93) and the ethics committee of The University of Manchester (ref. 08117). This study was approved by Thai Clinical Trial Registry (TCTR: 20190605004). The information sheet and consent form were distributed to nurses before the study began. Three hundred forty participating nurses had signed in the consent form to confirm that they all agreed to take part of this study.

\section{Questionnaire}

Information on personal demographics (i.e. personal lifestyle), health status (i.e. history of ill-health, symptoms related to NRL gloves use) and occupational factors (i.e. working conditions and use of NRL gloves) were collected using a self-completed questionnaire. This questionnaire was translated to Thai language and back-translated into English by a second bi-lingual researcher to ensure consistency and the clarity of translation. The content validity was considered by three experts. The index of item objective congruence (IOC) was 0.92 .

\section{Spirometry}

Spirometry was measured using an electronic spirometer (Micro Medical MicroLab 3500, Cardinal Health, UK) using standard procedures and calibrated using normal values for the population of Thailand. ${ }^{20}$ Before the test, personal information such as age, weight and height were recorded. Nurses were asked to sit in a convenient position, take a deep breath and blow into a spirometer. This was repeated 3 times, and the best of three acceptable blows (largest value) was recorded. The forced expiratory volume at one second $\left(\mathrm{FEV}_{1}\right)$ and forced vital capacity (FVC) were based on the maximal inspiration and expiration of the subjects. The forced expiratory flow $\left(\mathrm{FEF}_{25-75}\right)$ was also recorded. The expected values were based on the age, sex and height of the subjects.

\section{Detection of anti-NRL immunoglobulin E (IgE) antibodies}

Nurses provided $5 \mathrm{ml}$ of blood. These samples were centrifuged $(4,000 \mathrm{~g})$ at room temperature for 15 minutes, the serum separated and transferred into microcentrifuge tubes. Serum levels of anti-NRL IgE antibody was measured using a solid-phase enzyme-labelled fluoroenzyme immunoassay (NRL UniCAP Specific IgE Assay) in which allergens were covalently linked to high-binding-capacity sponge matrices. Specific IgE antibodies present in serum react with the NRL allergens and non-specific IgE antibodies were removed by washing the matrices. Enzyme labeled antibodies against IgE antibodies were then added, followed by developing reagents. Fluorescence was measured and antibody levels determined using a calibration curve. A positive IgE antibody on NRL was a result $>35 \mathrm{kU}_{\mathrm{A}} / \mathrm{I}^{21}$

\section{Determination of protein levels in NRL glove extracts}

Two types of NRL gloves most used in medical procedures were selected for testing, namely powdered examination gloves (PEGs) and powdered surgical gloves (PSGs). Each type of NRL glove used in hospital 1 and 2 was produced by different glove companies. Crude water soluble proteins of these gloves were extracted and quantified by using a Modified Lowry method (the standard of The American Society for Testing Materials (ASTM) test D57122005 protocol). ${ }^{22}$ Briefly, proteins from PLGs were extracted into aqueous buffer solution for $\mathrm{pH} 7.4 \pm 0.2$ and then precipitated with sodium deoxycholate to concentrate them and to separate them from water soluble substances. The proteins were then redissolved in alkali and quantified colorimetrically by a Modified Lowry method. Spectrophotometric measurement was performed at a wavelength of $750 \mathrm{~nm}$. The concentrations of protein in NRL gloves were reported in microgram per gram $(\mu \mathrm{g} / \mathrm{g})$ of $\mathrm{NRL}$ glove. The sensitivity of this method is $50 \mu \mathrm{g} / \mathrm{g}{ }^{23}$ 


\section{Statistical Analysis}

Exploratory data analyses were conducted using frequency tables. Continuous data were described using mean, median, standard deviation, minimum and maximum values. Chisquare tests were used to analyse the difference in categorical variables. Fisher's exact test was used to analyse for small cell counts $(\mathrm{n}<5)$. Mann Whitney $\mathrm{U}$ tests were used to analyse data when the assumption of the t-test was not met. Analysis of covariance (ANCOVA) was used to analyse effects of sensitization to latex on pulmonary functions. Statistical significance was considered when $p$-values were lower than 0.05 .

\section{Results}

Of 664 nurses, 340 (51.2\% response rate) completed the questionnaires, underwent a blood test and also spirometry. Detectable levels of IgE antibodies to NRL were found in $4.7 \%$ of participating (16 of 340 nurses). The demographics of this population were described in Table 1 . There were border significant differences on age and work period between NRL sensitized and non-sensitized nurses $(p=0.07)$.

\section{Table 1. Characteristics of nurses}

\begin{tabular}{|c|c|c|c|c|}
\hline Variable & $\begin{array}{l}\text { All nurses } \\
(n=340)\end{array}$ & $\begin{array}{l}\text { Latex sensitized } \\
\text { cases } \\
(\mathbf{n}=16)\end{array}$ & $\begin{array}{c}\text { Non-latex sensitized } \\
\text { cases } \\
(\mathbf{n}=324)\end{array}$ & $P$-value \\
\hline Age (years) & & & & $0.07^{\mathrm{a}}$ \\
\hline Mean \pm SD & $36.9 \pm 8.3$ & $33.1 \pm 8.2$ & $37.1 \pm 8.3$ & \\
\hline Median & 35.0 & 33.0 & 35.0 & \\
\hline Min-Max & $23.0-60.0$ & $23-48$ & $23-60$ & \\
\hline BMI classification, n (\%) & & & & $0.49^{\mathrm{a}}$ \\
\hline Mean \pm SD & $22.1 \pm 3.4$ & $22.3 \pm 2.9$ & $22.1 \pm 3.4$ & \\
\hline Median & 21.4 & 22.4 & 21.36 & \\
\hline Min-Max & $116.0-34.5$ & $17.9-30.3$ & $16.0-34.5$ & \\
\hline Education, n (\%) & & & & 1.00 \\
\hline Diploma & $16(4.7)$ & $1(6.3)$ & $15(4.6)$ & \\
\hline Bachelor and over & $292(85.9)$ & $14(87.5)$ & $278(85.5)$ & \\
\hline Ethnicity, n (\%) & & & & $0.54^{\mathrm{c}}$ \\
\hline Thai & $269(79.1)$ & $14(87.5)$ & $255(78.7)$ & \\
\hline Thai-Chinese/Malaysian & $71(20.9)$ & $2(12.5)$ & $69(21.3)$ & \\
\hline Non-Smoker, n (\%) & $340(100.0)$ & $16(100.0)$ & $324(100.0)$ & - \\
\hline Personal history of allergic disease ( $\mathrm{Y} / \mathrm{N}, \%$ yes) & $134 / 206(39.4)$ & $5 / 11(31.3)$ & $129 / 195(39.8)$ & $0.49^{\mathrm{b}}$ \\
\hline \multicolumn{5}{|l|}{ Type of personal allergic disease } \\
\hline Hay fever (Y/N, \% yes) & $36 / 304(10.6)$ & $2 / 14(12.5)$ & $34 / 290(10.5)$ & $0.68^{c}$ \\
\hline Grass allergy (Y/N, \% yes) & $31 / 309(9.1)$ & $2 / 14(12.5)$ & $29 / 295(9.0)$ & $0.64^{\mathrm{c}}$ \\
\hline Eczema (Y/N, \% yes) & $56 / 284(16.5)$ & $1 / 15(6.3)$ & $55 / 269(17.0)$ & $0.48^{c}$ \\
\hline Hives (Y/N, \% yes) & $91 / 249(26.8)$ & $3 / 13(18.8)$ & $88 / 236(27.2)$ & $0.57^{\mathrm{c}}$ \\
\hline Asthma (Y/N, \% yes) & $16 / 324(4.7)$ & $2 / 14(12.5)$ & $14 / 310(4.3)$ & $0.17^{\mathrm{c}}$ \\
\hline Autoimmune (Y/N, \% yes) & $5 / 335(1.5)$ & $0 / 16(0.0)$ & $5 / 319(1.5)$ & $1.00^{c}$ \\
\hline Atopy (Y/N, \% yes) & $87 / 253(25.6)$ & $3 / 13(18.8)$ & $84 / 240(25.9)$ & $0.77^{\mathrm{c}}$ \\
\hline Family history of allergic diseases (Y/N, \% yes) & $153 / 187(45.0)$ & $8 / 8(50.0)$ & $145 / 179(44.8)$ & $0.68^{\mathrm{b}}$ \\
\hline
\end{tabular}


Table 1. (Continued)

\begin{tabular}{|c|c|c|c|c|}
\hline Variable & $\begin{array}{l}\text { All nurses } \\
(\mathrm{n}=340)\end{array}$ & $\begin{array}{l}\text { Latex sensitized } \\
\text { cases } \\
(n=16)\end{array}$ & $\begin{array}{c}\text { Non-latex sensitized } \\
\text { cases } \\
(\mathrm{n}=324)\end{array}$ & $P$-value \\
\hline \multicolumn{5}{|l|}{ Type of family allergic disease } \\
\hline Hay fever (Y/N, \% yes) & $37 / 303(10.9)$ & $3 / 13(18.8)$ & $34 / 290(10.5)$ & $0.39^{c}$ \\
\hline Grass allergy (Y/N, \% yes) & $29 / 311(8.5)$ & $2 / 14(12.5)$ & $27 / 297(8.3)$ & $0.63^{c}$ \\
\hline Eczema (Y/N, \% yes) & 65/275 (19.1) & $2 / 14(12.5)$ & 63/261 (19.4) & $0.74^{c}$ \\
\hline Hives (Y/N, \% yes) & $84 / 256(24.7)$ & $3 / 13(18.8)$ & $81 / 243(25.0)$ & $0.76^{\mathrm{c}}$ \\
\hline Asthma (Y/N, \% yes) & $67 / 273(19.7)$ & $2 / 14(12.5)$ & $65 / 259(20.1)$ & $0.74^{c}$ \\
\hline Autoimmune (Y/N, \% yes) & $9 / 331(2.6)$ & $1 / 15(6.3)$ & $8 / 316(2.5)$ & $0.35^{\mathrm{c}}$ \\
\hline Atopy (Y/N, \% yes) & $122 / 218(35.9)$ & $6 / 10(37.5)$ & $116 / 208(35.8)$ & $1.00^{c}$ \\
\hline Position, n (\%) & & & & $0.57^{\mathrm{b}}$ \\
\hline Registered nurses & $323(95.0)$ & $15(93.8)$ & $308(95.1)$ & \\
\hline Practical or Technical nurses & $17(5.0)$ & $1(6.3)$ & $16(4.9)$ & \\
\hline \multicolumn{5}{|l|}{ Workplace, n (\%) } \\
\hline OPD & $31(9.1)$ & $0(0.0)$ & $31(9.6)$ & - \\
\hline ER & $19(5.6)$ & $0(0.0)$ & $19(5.9)$ & \\
\hline ICU & $60(17.6)$ & $1(6.3)$ & $59(18.2)$ & \\
\hline OR & $50(14.7)$ & $2(12.5)$ & $48(14.8)$ & \\
\hline LR & $23(6.8)$ & $3(18.8)$ & $20(6.2)$ & \\
\hline Sur & $74(21.8)$ & $4(25.0)$ & $70(21.6)$ & \\
\hline Obs & $33(9.7)$ & $4(25.0)$ & $29(9.0)$ & \\
\hline Med & $50(14.7)$ & $2(12.5)$ & $48(14.8)$ & \\
\hline \multicolumn{5}{|l|}{ Work period } \\
\hline Mean \pm SD & $14.7 \pm 8.5$ & $11.0 \pm 8.1$ & $14.9 \pm 8.5$ & $0.07^{\mathrm{b}}$ \\
\hline Median & 13.0 & 10.9 & 13.0 & \\
\hline Min-Max & $0.7-36.0$ & $0.8-24.1$ & $0.7-36$ & \\
\hline \multicolumn{5}{|l|}{ Work shift, n (\%) } \\
\hline$\leq 35$ hours/week & $133(39.2)$ & $5(31.3)$ & $128(39.6)$ & $0.61^{\mathrm{b}}$ \\
\hline > 35 hours/week & $206(60.8)$ & $11(68.8)$ & $195(60.4)$ & \\
\hline
\end{tabular}

${ }^{a} P$-value by Mann-Whitney U Test; ${ }^{b} P$-value by using Chi-Square Test; ${ }^{c} P$-value by using Fisher's Exact Test.

\section{Respiratory symptoms and pulmonary function}

Of 340 nurses, 22 nurses (6.5\%) reported respiratory symptoms related to NRL gloves used. Of 16 nurses with NRL sensitization, 4 sensitized nurses (25\%) had reported respiratory symptoms related to NRL gloves used. The respiratory symptoms included sneezing, rhinitis, shortness of breath, wheezing and asthma. NRL-sensitized nurses had lower $\mathrm{FEF}_{25-75 \%}$ predicted values than non-sensitized nurses (Adjusted difference $=-12.56(95 \% \mathrm{CI}-24.41$ to -0.70$)$; Table 2).

\section{Use of NRL glove and level of proteins in NRL gloves}

The results showed that PEGs had higher proteins than PSGs and there were different amount of protein levels in PEGs and PSGs between hospital 1 and 2. The protein levels were found in PEGs in the range of 111.1-250.8 ug/ $\mathrm{dm}^{2}$, while the NRL sterile gloves were found proteins in the range of $115.1-203.9 \mathrm{ug} / \mathrm{dm}^{2}$. Moreover, there were significant differences in the levels of proteins of PEGs and PSGs between hospital 1 and 2 (Mean difference $(95 \% \mathrm{CI})=139.76$ (112.53 to 166.99$)$ and 88.82 (64.19 to 113.44$)$, respectively). 
Table 2. Comparison of pulmonary function in sensitized and non-sensitized female nurses

\begin{tabular}{|c|c|c|c|c|}
\hline Variable & $\begin{array}{l}\text { Sensitized } \\
(\mathrm{n}=16) \\
\text { Mean } \pm \text { SD }\end{array}$ & $\begin{array}{l}\text { Non-sensitized } \\
(\mathrm{n}=324) \\
\text { Mean } \pm \text { SD }\end{array}$ & $P$-value & $\begin{array}{l}\text { Adj. difference } \\
\text { (95\% CI) }\end{array}$ \\
\hline $\mathrm{FEV}_{1}(\mathrm{~L})$ & $2.2 \pm 0.2$ & $2.2 \pm 0.3$ & $0.62^{\mathrm{a}}$ & $-0.04(-0.19$ to 0.11$)$ \\
\hline FVC (L) & $2.5 \pm 0.3$ & $2.5 \pm 0.4$ & $0.95^{\mathrm{a}}$ & $0.01(-0.17$ to 0.18$)$ \\
\hline $\mathrm{FEV}_{1} / \mathrm{FVC}$ ratio & $88.3 \pm 4.7$ & $89.7 \pm 5.5$ & $0.28^{\mathrm{a}}$ & $-1.51(-4.23$ to 1.21$)$ \\
\hline $\mathrm{FEV}_{1}(\%$ predicted $)$ & $90.7 \pm 10.2$ & $91.8 \pm 12.1$ & $0.74^{\mathrm{b}}$ & $-1.01(-7.03$ to 5.01$)$ \\
\hline FVC (\% predicted) & $90.3 \pm 11.5$ & $89.0 \pm 12.3$ & $0.69^{\mathrm{b}}$ & $1.26(-4.86$ to 7.37$)$ \\
\hline $\mathrm{FEF}_{25 \%-75 \%}$ predicted & $83.3 \pm 17.0$ & $95.8 \pm 23.8$ & $0.04^{\mathrm{b}}$ & $-12.56(-24.41$ to -0.70$)$ \\
\hline
\end{tabular}

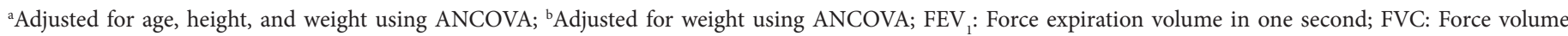
capacity; FEF: Force expiratory flow

Table 3. Comparison of number of NRL glove used, total proteins in NRL gloves, latex sensitization and respiratory symptoms in latex sensitized nurses between hospital 1 and 2

\begin{tabular}{|l|c|c|c|}
\multicolumn{1}{|c|}{ Variable } & $\begin{array}{c}\text { Hospital 1 } \\
\text { Mean } \pm \text { SD }\end{array}$ & $\begin{array}{c}\text { Hospital 2 } \\
\text { Mean } \pm \text { SD }\end{array}$ & $\begin{array}{c}\text { Mean Difference } \\
\text { (95\%CI) }\end{array}$ \\
\hline Average number of NRL examination glove used per day & $9.9 \pm 9.5$ & $9.1 \pm 9.3$ & $0.80(-1.36$ to 2.96) \\
Average number of NRL surgical glove used per day & $6.7 \pm 9.4$ & $6.3 \pm 7.2$ & $0.41(-1.71$ to 2.54$)$ \\
Average total protein of powdered examination gloves $\left(\mathrm{ug} / \mathrm{dm}^{2}\right) \pm \mathrm{SD}$ & $250.8 \pm 16.0$ & $111.1 \pm 5.6$ & $139.76(112.53$ to 166.99$)$ \\
Average total protein of powdered surgical gloves $\left(\mathrm{ug} / \mathrm{dm}^{2}\right) \pm \mathrm{SD}$ & $203.9 \pm 13.0$ & $115.1 \pm 8.2$ & $88.82(64.19$ to 113.44$)$ \\
Latex sensitization $(\%)$ & 6.9 & 2.4 & $<0.01$ \\
\hline Respiratory symptoms in latex sensitized nurses $(\mathrm{n}=4)$ & 4 & $<0.01$ \\
\hline
\end{tabular}

$P$-value by Independent $t$ test

According to the consequence above, high latex sensitization was found in the hospital where NRL gloves with high protein levels were used $(6.9 \%$ vs $2.4 \%, p=0.04)$. Furthermore, the latex sensitized nurses working in hospital 1 where used NRL gloves with high proteins had reported respiratory symptoms, while the NRL sensitized nurses in hospital 2 where used NRL gloves with low protein levels had not found, as shown in Table 3.

\section{Discussion}

High levels of water soluble proteins were found PLGs, particularly PEGs. However, it has been showed that the low water soluble protein level was found in powder free examination glove, as a study in Germany had evaluated the amount of proteins from powdered free gloves using a modified Lowry method. The results showed that 13 of 18 powder free gloves contained protein between 7.1 and $92.3 \mu \mathrm{g}$ protein/g, while another 5 gloves were found under detection limit. ${ }^{25}$ The German technical standards for hazardous material (TRGS 540) has been recommended that protein levels of NRL glove should be less than $30 \mu \mathrm{g}$ proteins/g. ${ }^{24,25}$ According to the results in this current study, level of proteins in PLGs was eight times higher than the recommend value.
The prevalence of NRL sensitization was higher where PLGs of high protein content were used suggesting an association between the two. This result supported the findings of a previous study which reported a decrease of NRL sensitization and allergic symptoms related to NRL glove use when low protein NRL gloves were used in hospital workplaces. ${ }^{26}$ For the respiratory symptoms which had found in 4 sensitized nurses, all of them worked in the hospital 1 where NRL gloves with high water soluble protein levels were used, while sensitized nurses in Hospital 2, where NRL gloves with low water soluble protein level were used, had not found respiratory symptoms. This may assume that NRL glove with a high protein level had also had a high level of NRL allergens. As, a previous study found that PEGs has highly released an amount of NRL aeroallergens which $68 \%$ of released particles sized was in the range of particle meter between 2.5 and 10 micron, and also 56\% NRL aeroallergens were carried on them. ${ }^{27}$

Exposure to NRL allergens among sensitized nurses in this study was associated with a decline in pulmonary function, particularly the $\mathrm{FEF}_{25-75 \%}$ predicted value, while there was no evidence of effect on the other pulmonary functions. The $\mathrm{FEF}_{25-75 \%}$ is a parameter which is more reflective of small airways and sensitive indicator of symptomatic asthma. ${ }^{28}$ 
Another study on $\mathrm{FEF}_{25-75}$ in Italy reported that the abnormal $\mathrm{FEF}_{25-75}$ was an early marker of airflow limitation and it had also suggested that the $\mathrm{FEF}_{25-75}$ can be a predictive marker of newly diagnosed asthma. ${ }^{29}$ It also has been reported that the reduced $\mathrm{FEF}_{25-75}$ ( $<65 \%$ of predicted value) was associated with bronchial hyperreactivity. ${ }^{30} \mathrm{FEF}_{25-75}$ could be used to predict airway hyper responsiveness in adult patient with asthma. Low $\mathrm{FEF}_{25-75 \%}$ predicted value can show that there is decreased function in the small airways of the lung. However, $\mathrm{FEF}_{25-75 \%}$ predicted values are not specific for small airway diseases, ${ }^{31}$ but is a sensitive indicator for airway obstruction. ${ }^{32}$ $\mathrm{FEF}_{25-75 \%}$ predicted value is more sensitive than $\mathrm{FEV}_{1}$ in detecting peripheral or small airway narrowing in adults ${ }^{13}$ as well as identifying individuals with asymptomatic asthma. ${ }^{34}$ A previous study on the clinical diagnosis of asthma and $\mathrm{FEF}_{25-75 \%}$ predicted value had been compared the baseline $\mathrm{FEF}_{25-75 \%}{ }^{25-75 \%}$ predicted value using the subsequent methacholine bronchial provocation test and the results on $\mathrm{FEF}_{25-75 \%}$ predicted value in patients with positive bronchial provocation test had significantly lower that patient with normal responsive airway $(\mathrm{t}=4.616, p<0.001) .{ }^{35}$ The change of small airways may be one of initially presenting parameters of a respiratory reaction in NRL sensitized nurses who worked in the environment with PLG use.

In the past years, there had numerous articles about NRL allergy in health care workers and also the study of NRL allergens in NRL gloves and other NRL products. Various types of glove used had different levels of proteins. These proteins were contained with NRL allergens inducing NRL sensitization in the health care workers. In developing countries as Thailand, the PLGs were widely used in hospitals for a long time until now. There were few studies about NRL allergy from NRL gloves exposed in Thai health care workers and no report for the proteins extracted from NRL glove and NRL sensitization (anti-NRL IgE antibodies) in Thai nurses. This current study revealed more information on the NRL sensitization, amount of glove proteins, respiratory symptoms and pulmonary functions in nurses working in governmental hospitals.

The limitations of this study were that the voluntary participation may have resulted in volunteer bias in that nurses who reported health problems may have been overrepresented compared to nurses who were healthy. Furthermore, the healthy worker effects may be found in this study due to some evidences showed that non-sensitized nurse are older and have worked longer than sensitized nurses. The sensitized nurses might change their job positions due to health problems related to gloves used before the study was done. This study collected the self-reported data of respiratory symptoms related to gloves used, but fixed choice questions may lack flexibility and forces to answer and also social desirability bias may occur. The self-reported symptoms may occur not only expose to NRL allergens, but also chemical and powder cornstarch from PLGs. The design of this study cannot derive causal relationship between pulmonary function and proteins of NRL glove exposure and NRL sensitization. Furthermore, the confounding factors such as secondary smoking, underlying lung disease or allergic diseases may affect the result of pulmonary function test.
In conclusion, there was moderate evidence that exposure to NRL airborne allergens in the healthcare sector can affect pulmonary function of sensitized workers as measured by $\mathrm{FEF}_{25-75 \%}$ predicted value. The evidences in this study revealed exposure to high level protein in NRL glove has affected the respiratory and the low $\mathrm{FEF}_{25-75 \%}$ predicted value where found in sensitized nurses. This suggests that it is important to minimize the level of NRL aeroallergens in the workplace environment by using powder free gloves or synthetic latex free gloves, which can reduce the risk of respiratory ill-health in NRL sensitized HCWs.

\section{Acknowledgements}

The researcher would like to thank the director of Yala and Hat Yai Hospital and also all nurses who were participating in this study.

\section{References}

1. Gazmán MA, Arancibia V, Salinas J, Rodas C, Roa J, Villegas R. Prevalence of latex hypersensitivity in operating room workers of the university of chile clinical hospital. Rev Med Chil. 2005;133:535-40.

2. Jin C,Hantusch B, Hemmer W, Stadlmann J, Altmann F. Affinity of IgE and IgG against cross-reactive carbohydrate determinants on plant and insect glycoproteins. J Allergy Clin Immunol. 2008;121:185-90.

3. Moreno HI, Avila E, Angulo Y, Portillo J, Moreno L, Reza G, Hernández V, Levario $M$. Frequency in allergy to proteins of latex in health care workers. Allergol Immunopathol. 2005;33:210-3.

4. Lee MF, Wang NM, Han SJ, Lin SJ, Tsai JJ, Chen YH. Estimating allergenicityof latex gloves using Hevb 1 and Hevamine. J Investig Allergol Clin Immunol. 2010;20:499-505.

5. Wright HT, Brooks DM, Wright CS. Evolution of the multidomain protein wheat germ agglutinin. J Mol Evol. 1985;102:418-9.

6. Baur X, Chen Z, Allmers H. Can a threshold limit value for natural rubber latex airborne allergens be defined? J Allergy Clin Immunol. 1998;101:24-7.

7. Supapvanich C, Povey AC, de Vocht F. Respiratory and dermal symptoms in Thai nurses using latex products. Occup Med (Lond). 2013;63:425-8.

8. Boonchai W, Sirikudta W, Kasemsarn P. Characteristics of latex glove usage and glove-related symptoms among health care workers in each work sector of a University hospital. J Med Assoc Thai.2017;100:558-64.

9. Zak HN, Kaste L, Schwarzenberger K, Barry MJ, Galbraith GMP. Health-care workers and latex allergy. Arch Environ Occup Health. 2000;55:336-46.

10. Amarasekera $M$, Rathnamalala $N$, Samaraweera S, Jinadasa $M$. Prevalence of latex allergy among healthcare workers. Int J Occup Med Environ Health. 2010;23:391-6.

11. Pollart SM, Warniment C, Mori T. Latex allergy. Am Fam Physician. 2009;80:1413-8.

12. Liberatore K, Kelly K. Latex allergy risks live on. J Allergy Clin Immunol Pract. 2018;6:1877-8.

13. Yunginger JW, Jones RT, Fransway AF, Kelso JM, Warner MA, Hunt LW. Extractable latex allergens and proteins in disposable medical gloves and other rubber products. J Allergy Clin Immunol. 1994;93:836-42.

14. Risenga SM, Shivambu GP, Rakgole MP, Makwela ML, Nthuli S, Malatji TA. Latex allergy and its clinical features among healthcare workers at Mankwenghospital Limpopo province, South Africa. S Afr Med J. 2013;103:390-4.

15. Tarlo SM, Easty A, Eubanks K, Parsons CR, Min F, Juvet S. Outcomes of a natural rubber latex control program in an Ontario teaching hospital. J AllergyClin Immunol. 2001;108:628-35.

16. Turjanmaa K. Natural rubber latex allergy: clinical manifestations (including contact dermatitis) and diagnosis. Rev Fr Allergol. 1997;37: 1177-84

17. Vandenplas O, Binard-Van Cangh F, Brumagne A, Caroyer JM, Thimpont J, Sohy C, et al. Occupational asthma in symptomatic workers exposed to natural rubber latex: evaluation of diagnostic procedures. J Allergy Clin Immunol. 2001;107:542-7. 
18. Laoprasert N, Swanson M, Jones RJ, Schroeder DR. Inhalation challenge testing of latex sensitive health care workers and the effectiveness of laminar flow hepa-filtered helmets in reducing rhinoconjunctival and asthmatic reactions. J Allergy Clin Immunol. 1998;102:998-1004.

19. Kelly KJ, Wang M, Klancnik M, Petsonk EL. Prevention of ige sensitization to latex in health care workers after reduction of antigen exposure. JOccup Environ Med. 2011;53:934-40.

20. Dejsomritrutai W, Maranetra KN, Maneechotesuwan K, Chierakul N, Tscheikuna J, Suthamsmai T, et al. Reference spirometric values for healthy lifetime nonsmokers in Thailand. J Med Assoc Thai. 1999;83: 457-66.

21. Pharmacia Diagnostic AB US [Internet]. Uppsala;c2010 [cited 2010 Jun 7]. UniCAPSpecific IgE: Fluoroenzyme immunoassay;[about 5 screens]. Available from: http://www.phadia.us/upload/US/Product_information/ Files/Directions\%20for20Use/ImmunoCAP\%20Specific\%20IgE\%200-100 \%20-DFU-US\%20final.pdf

22. Lucus AD, Tomazic-Jezic VJ. Modification of the lowry method for analysis of soluble latex proteins. Toxicol Mech Methods. 2008;10:165-79.

23. Mikkola JH, Alenius $\mathrm{H}$, Kalkkinen N, Turjanmaa K, Palosuo T, Reunala T. Hevein-like protein domains as a possible cause for allergen cross-reactivity between latex and banana. J Allergy Clin Immunol. 1998; 102:1005-12.

24. von der Gathen Y, Sander I, Flagge A, Brüning T, Raulf-Heimsoth M. Quantification of protien and latex allergen content of various natural rubber latex products. Allergol Select. 2017;1:109-19.

25. Federal Institute for Occupational Safety and Health [Internet]. Berlin: Technical rules for hazardous substances (TRGS) 540. Baua; c2000 [cited 2018 Apr 7]. Available from: http://ka4-umwelt.de/uploads/media/ TRGS-540.pdf

26. Reinikka-Railo H, Kautiainen H, Alenius H, Kalkkinen N, Kulomaa M, Reunala T, et al. Latex allergy: the sum quantity of four major allergens shows the allergenic potential of medical gloves. Allergy. 2007;62:781-7.
27. Brown RH, Taenkhum K, Buckley TJ, Hamilton RG. Different latex aeroallergen size distributions between powdered surgical and examination gloves: significance for environmental avoidance. J Allergy Clin Immunol. 2004;114:358-63.

28. Rao DR, Gaffin JM, Baxi SN, Sheehan WJ, Hoffman EB, Phipatanakul W. The utility of forced expiratory flow between $25 \%$ and $75 \%$ of vital capacity in predicting childhood asthma morbidity and severity. J Asthma. 2012;49:586-92.

29. Ciprandi G, Gallo F, Cirillo I. $\mathrm{FEF}_{25-75}$ and asthma in clinical practice. Iran J Allergy Asthma Immunol. 2018;17:295-7.

30. National heart, lung and blood institue. National asthma education and prevention program: Expert Panel Report 3: Guidelines for the diagnosis and management of asthma [Internet]. Bethesda: U.S. Department of Health and Human Services. 2007 [cited 2017 May 7]. Available from https://www.nhlbi.nih.gov/sites/default/files/media/docs/asthgdln_1.pdf

31. Pellegrino R, Viegi G, Brusasco V, Crapo RO, Burgos F, Casaburi R, et al. Interpretative strategies for lung function tests. Eur Respir J. 2005;26: 948-67.

32. Lebecque P, Kiakulanda P, Coates AL. Spirometry in the asthmatic child is $\mathrm{FEF}_{25-75}$ a more sensitive test than $\mathrm{FEV}_{1} / \mathrm{FVC}$ ? Pediatr Pulmonol. $1993 ; 16: 19-22$

33. Johns DP, Pierce R. Pocket guide to spirometry. Australia: Mcgraw-Gill Australia Pty Ltd; 2003.

34. Chiang $\mathrm{CH}$, Hsu K. Residual abnormalities of pulmonary function in asymptomatic young adult asthmatics with childhood-onset asthma. J Asthma. 1997;34:15-21.

35. Albert WM, Ferris MC, Brooks SM, Goldman AL. The FEF ${ }_{25-75 \%}$ and the clinical diagnosis of asthma. Ann Allergy. 1994;73:221-5. 